\title{
Endogenous Free Polyamines of Mangos in Relation to Development and Ripening
}

\author{
Aman Ullah Malik and Zora Singh ${ }^{1}$ \\ Horticulture/Viticulture, Muresk Institute, Division of Resources and Environment, Curtin University of \\ Technology, GPO Box U 1987, Perth 6845 Western Australia
}

AdDitional INDEX words. putrescine, spermine, spermidine, cell division, ovule, skin, pulp, ethylene, Mangifera indica

\begin{abstract}
Changes in endogenous free polyamines (putrescine, spermidine, spermine) were monitored from fruit set (fruit diameter $4.6 \pm 0.5 \mathrm{~mm}$, wt $0.09 \pm 0.05 \mathrm{~g}$ ) until 1 week before the expected harvest time in 'Kensington Pride' and 'Glen'

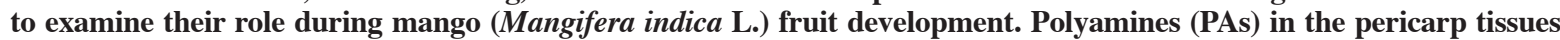
(exocarp and mesocarp) were estimated throughout the fruit development period, while estimations from growing ovules were started from 41 days after fruit set (DAFS). During fruit ripening, ethylene production and endogenous free PAs in skin and pulp of 'Kensington Pride' mango were also monitored. PA contents of pericarp declined between fruit set and maturity from 788 to $101 \mathrm{nmol} \cdot \mathrm{g}^{-1}$ fresh weight (FW) in 'Kensington Pride' and from 736.6 to $89.6 \mathrm{nmol} \cdot \mathrm{g}^{-1} \mathrm{FW}$ in ' $\mathrm{Glen}$ ' during fruit development. Spermidine (SPD) and spermine (SPM) were higher than putrescine (PUT) during the initial phase of fruit growth. The highest levels of free PAs, especially SPD and SPM, at the initial stages of fruit growth suggest a potential role during the cell division phase and not in subsequent fruit development. Ovule seems to be a rich source of PAs as evident from 2.3- and 2.7-fold higher total PAs than pericarp tissues in 'Kensington Pride' and 'Glen', respectively. During fruit ripening of 'Kensington Pride', total PAs increased in skin and pulp tissues along with the climacteric rise of ethylene, and reached maximum levels (skin 796, pulp $314 \mathrm{nmol} \cdot \mathrm{g}^{-1} \mathrm{FW}$ ) on day 4 of ripening. Skin exhibited 55.8\% higher mean free PAs than the pulp. PUT dominated both in skin and pulp tissues. The simultaneous increase of ethylene and free PAs during fruit ripening suggests that their biosynthesis may not be competitive, and free PAs may have evolved as a response to increased biosynthesis of ethylene.
\end{abstract}

Mango fruit growth and development have been associated with changes in endogenous plant growth substances (Ram, 1992). Endogenous levels of auxins, gibberellins, cytokinins, abscissic acid (ABA) and ethylene have been determined during mango fruit growth and development (Murti and Upreti, 1995; Ram, 1992). However, biosynthesis and distribution of PAs in relation to mango fruit growth and development is yet unknown. PAs are implicated in fruit growth and development because of their ubiquitous presence in all cells (Smith, 1985).

Putrescine (PUT), spermidine (SPD), and spermine (SPM), are the most commonly found polyamines (PAs) in plants. Changes in PAs during fruit development and ripening imply a significance in such processes, however, the precise role of PAs is not clear (Shiozaki et al., 2000). Exogenous application of PAs have been reported to increase the endogenous levels of PAs and fruit size (Biasi et al., 1991), indicating that the lower levels of these compounds could be growth limiting. Higher endogenous PAs level is also correlated with tolerance against a number of biotic and abiotic stresses (Bouchereau et al., 1999). Polyamines are synthesized from ornithine, arginine, and S-adenosyl methionine (SAM) and three of the enzymes involved are amino acid decarboxylases (Malmberg et al., 1998). PAs share a common precursor with ethylene (SAM), but show opposite effects in relation to the senescence processes

Received for publication 11 May 2003. Accepted for publication 4 Dec. 2003 We are thankful to Westralian Fruits, Gingin, Western Australia for provision of mango trees and other facilities used to conduct this study. We also thank Sandro Bambardieri and Peter Sheppard for their assistance in the analysis of polyamines. The authors are grateful to A.S. Basra, J.K. Brecht (Univ. Florida), and M.H. Behboudian (Massey Univ., New Zealand) for critically review of this manuscript. A. U. Malik also acknowledges the financial support of Curtin University of Technology, Perth, Western Australia, for an International Postgraduate Research Scholarship, the Australian International Development Program for an ADS scholarship, and the University of Agriculture, Faisalabad, Pakistan, for granting study leave during this period.

'To whom reprint requests should be addressed; e-mail Z.Singh@curtin.edu.au.
(Kakkar and Rai, 1993). The mechanism by which they interact with each other is not yet clear. Mutational and transgenic studies suggest interactions between endogenous PAs and either ethylene or cytokinins (Malmberg et al., 1998) and demonstrate the role of PAs in growth, development and ripening (Kumar et al., 1996).

Higher levels of PAs during the initial fruit growth period, progressively declining toward maturity, have been reported in various fruits including apple (Malus domestica Borkh.) (Biasi etal., 1988), grapes (Vitis vinifera L.) (Geny et al., 1997), tomato (Lycopersicon esculentum Mill.) (Morilla et al., 1996), and peach (Prunus perscia L.) (Kushad, 1998). However, in muskmelon (Cucumis melo L.), SPM and PUT increased with fruit development until $35 \mathrm{~d}$ after anthesis (Lester, 2000). During fruit ripening, increased levels of PAs have been reported in mandarins (Citrus reticulata Blanco 'Murcott') (Nathan et al., 1984), cherimoya (Annona cherimola Mill.) (Escribano and Merodio, 1994), and rambutans (Nephelium lappesium L.) (Kondo et al., 2001). However, in plum (Prunus salicina Lindl.), 'Golden Japan', which exhibited a nonclimacteric ripening process showed increased PAs toward maturity compared to 'Santa Rosa', which had a climacteric pattern of ripening ( $\mathrm{Zu}-$ zunaga et al., 2001). Thus, it may be surmised that variation in the trends of PAs biosynthesis and their endogenous levels not only exist between different species but also within a species and with differences in tissue types and stages of development.

The role of the embryo in fruit development should also be taken into account, since seeds are considered as a source of phytohormones (Nitsch, 1970). In peaches, seed tissues exhibited a burst of PAs during the pit hardening stage, but the levels of PAs in mesocarp tissues did not increase (Kushad, 1998). Contrarily in grapes, the increase in PAs in seeds corresponded to the time of PAs increase in mesocarp (Shiozaki et al., 2000). In mango, the work related to endogenous PAs has been limited to fruitlet abscission (Malik and Singh, 2003a; Murti and Upreti, 1999) and chilling injury (Nair, 2002; Whangchai et al., 2000). The potential role of the embryo in relation to changes in PAs during fruit 
development is also not known. Although, PAs exist in both free and bound forms (conjugates to various phenolic secondary metabolites) in plants (Evans and Malmberg, 1989), their free form seems to be more actively involved in biological processes as is evident from their translocation within the plant (Antognoni et al., 1998). Hence, we examined the changes in endogenous free PAs (PUT, SPD, and SPM) in pericarp and ovule in relation to mango fruit development to test if they are significantly changed during different developmental phases. PAs biosynthesis in skin and pulp in relation to ethylene production during ripening was investigated to test whether endogenous free PAs decline with increased biosynthesis of ethylene due to competition for SAM, a common metabolite in both biosynthetic pathways.

\section{Materials and Methods}

Experiments were conducted to determine free PAs in pericarp and ovule during fruit development (Expt. 1), endogenous levels in the pericarp of nubbins (seedless) and seeded fruit (Expt. 2), and changes in endogenous free PAs and ethylene during fruit ripening (Expt. 3).

\section{ENDOGENOUS POLYAMINES DURING FRUIT GROWTHAND DEVELOPMENT}

Plant materials. Fifteen-year-old 'Kensington Pride' and 'Glen' mango (Mangifera indica L.) trees, grown at Westralian Fruits, Gingin (Long 115 ${ }^{\circ} 55^{\prime} \mathrm{E}$; Lat. 31'221'S) Western Australia were used for this experiment. The trees were growing at $6 \mathrm{~m}$ between rows and $3 \mathrm{~m}$ between trees. All the experimental trees received similar cultural practices (Johnson and Parr, 1998).

Fruit GrowTH. Data on fruit growth were recorded by measuring fruit diameter (mm), weight ( $\mathrm{g}$ ) of 10 individual fruit per tree. A single tree was treated as a treatment unit and the treatments were replicated three times. The growth measurements were taken at day 0 (fruit set), and 14, 24, 41, 57, 72, 85, 99, and $109 \mathrm{~d}$ after fruit set (DAFS). Fruit diameter was taken from randomly-selected fruit for the first three observations. After the initial period of heavy fruitlet abscission was over (41 DAFS), 20 healthy, uniform fruit per tree were tagged and subsequent measurements were recorded on 10 of 20 fruit. The remaining 10 fruit were kept to overcome the risk of fruit drop. At each date, fruit weight was determined on 10 fruit of the same diameter as the tagged ones.

Collection OF SAMPLES FOR POLYAMINE ANALYSIS. Fruit sampling was started from fruit set (fruit diameter $4.6 \pm 0.5 \mathrm{~mm}$, weight $0.09 \pm 0.05 \mathrm{~g}$ ) and continued until 1 week before commercial fruit maturity. Samples were taken at day 0 , and 14, 24, 41, 57, 72, 85, 99, and 109 DAFS. PAs were estimated from pericarp tissues throughout fruit development. Sampling for ovule tissues was started from 41 DAFS along with pericarp. At each sampling, uniform, healthy intact fruit (10 fruit at day 0 and 14, as fruit were small sized, and subsequently two fruit from 24-109 DAFS), of both cultivars were randomly selected, packed in plastic bags, and transported to the laboratory on ice. Pericarp or ovule tissues from each replicate were cut into small pieces on ice and individual samples $(1 \mathrm{~g})$ in triplicate were wrapped in aluminium foil and stored in sealed plastic vials in a freezer $\left(-20^{\circ} \mathrm{C}\right)$ till analyzed.

\section{ENDOGENOUS POLYAMINES IN NORMAL (SEEDED) AND NUBBINS (SEEDLESS) FRUIT}

After 41 DAFS, three normal and three nubbins fruit were picked randomly from each tree replication. Chopped pericarp tissues (1 g) were used for estimation of endogenous free PA contents.

\section{ENDOGENOUSPOLYAMINESANDETHYLENEDURINGFRUIT RIPENING}

MangofruitandriPENINGCONDITIONS. Mature, green 'Kensington Pride' mango fruit of firmness $120.5 \pm 10.8 \mathrm{~N}, \mathrm{CO}_{2}$ production rate $0.63 \pm 0.06 \mathrm{mmol} \cdot \mathrm{kg}^{-1} \cdot \mathrm{h}^{-1}$, and ethylene production rate $0.82 \pm$ $0.05 \mathrm{nmol} \cdot \mathrm{kg}^{-1} \cdot \mathrm{h}^{-1}$, from a commercial property in Chittering (Long $116^{\circ} 5^{\prime} \mathrm{E}$; Lat $\left.31^{\circ} 25^{\prime} \mathrm{S}\right)$, Western Australia, were used for these studies. After harvest, fruit free from visual symptoms of disease or blemish were selected and treated with a solution of sportak (prochloraz a.i. $450 \mathrm{~g} \cdot \mathrm{L}^{-1}$ ) at $55 \mathrm{~mL} / 100 \mathrm{~L}$ for $30 \mathrm{~s}$ for disease control. Fruit were allowed to drain and dry at ambient temperature before packing in Ecopax mango trays with special inside liners. The fruit were ripened at ambient temperature $\left(22 \pm 1^{\circ} \mathrm{C}\right)$.

ETHYLENE ESTIMATION. Ethylene production was estimated by placing individual fruit samples in airtight sealed jars $(1000 \mathrm{~mL})$ for $1 \mathrm{~h}$ at $22^{\circ} \mathrm{C}$. Headspace gas samples $(1 \mathrm{~mL})$ were injected into a gas chromatograph (series Star 3400 CX; Varian , Walnut Creek, Calif.) equipped with flame ionization detector and $2 \mathrm{~m}$ stainless steel Porapak Q column (O.D. 3.175 mm, 80/100 mesh). Nitrogen was used as the carrier gas with a head pressure of $206.8 \mathrm{kPa}$. The injector and column temperature (isothermal) was $100^{\circ} \mathrm{C}$ and detector at $150^{\circ} \mathrm{C}$. Ethylene production was estimated from 0 to $8 \mathrm{~d}$ of ripening period and expressed as nmol $\mathrm{kg}^{-1} \cdot \mathrm{h}^{-1}$.

ESTIMATION OF RESPIRATION RATE. $\mathrm{CO}_{2}$ production rate was measured by taking 2-mL headspace gas samples from the jars as explained above, and injecting into an Infrared gas analyser (Servomex Series 1400, Crowborough, Sussex, England). $\mathrm{CO}_{2}$ production was expressed as $\mathrm{mmol} \cdot \mathrm{kg}^{-1} \cdot \mathrm{h}^{-1}$.

Polyamine analyses. Fruit skin and pulp samples (tissues of two fruit/sample) in triplicate were taken during the fruit ripening period at 0, 2, 4, 6,and $8 \mathrm{~d}$ after harvest, for endogenous free PA analyses.

EXTRACTION AND QUANTIFICATION OF POLYAMINES. Endogenous PAs were estimated by following the method detailed by Flores and Galston (1982), with some modifications. Samples (1 g) along with internal standard (20 $\mu \mathrm{L}$ of $5 \mathrm{~mm} 1-6$ hexane diamine) were homogenized in $10 \mathrm{~mL}$ cold $5 \%$ by volume $\mathrm{HClO}_{4}$ using a mortar and pestle. Homogenates were extracted on ice for $2 \mathrm{~h}$ before centrifugation at $4800 g_{\mathrm{n}}$ for $30 \mathrm{~min}$. The supernatant phase (500 $\mu \mathrm{L}$ ) containing free PAs was collected in ether-nonreactive plastic tubes, to which $1 \mathrm{~mL} 2 \mathrm{~N} \mathrm{NaOH}$ and $10 \mu \mathrm{L} 99 \%$ by volume benzoyl chloride per sample was added. Samples were vortexed for $10 \mathrm{~s}$ and kept for $20 \mathrm{~min}$ at room temperature $\left(24 \pm 1^{\circ} \mathrm{C}\right)$ for completion of the benzoylation process. Saturated $\mathrm{NaCl}$ solution $(2 \mathrm{~mL})$ was added to each sample to terminate the reaction. Benzoylated free PAs derivatives were extracted in chilled $2 \mathrm{~mL}$ anhydrous diethyl ether $\left(\mathrm{Et}_{2} \mathrm{O}\right)$. After vortexing for $5 \mathrm{~s}$ and $5 \mathrm{~min}$ centrifugation at $450 g_{n}, 1 \mathrm{~mL}$ of the $\mathrm{Et}_{2} \mathrm{O}$ phase was collected in a 2-mL HPLC standard vial and evaporated to dryness at room temperature (24 $\pm 1^{\circ} \mathrm{C}$ ). The free PAs were redissolved in $100 \mu \mathrm{L}$ of ethanol and $20 \mu \mathrm{L}$ of this aliquot was injected into a high-performance liquid chromatograph (HPLC) for estimating PAs. The HPLC was a Waters 590, dual-head reciprocating pump and Waters 486 tunable detector fitted with Waters Spherisob $5 \mu \mathrm{m}$ ODS2 $(4.6 \times 250 \mathrm{~mm})$ analytical column and UV-detector measuring absorbance at 254 $\mathrm{nm}$. The solvent system consisted of 49.5 acetonitrile : 51.5 water (by volume, $\mathrm{pH} 3.5$ ) run isocratically at $1 \mathrm{~mL} \cdot \mathrm{min}^{-1}$. PAs were quantified by comparison of the integration areas from the samples with those of standards and expressed as on a fresh weight (FW) basis $\mathrm{nmol} \cdot \mathrm{g}^{-1}$ of sample. All the standards were prepared in 0.01 $\mathrm{N} \mathrm{HCl}$ and derivatized in the same way as the samples.

Statisticalanalysis. The experimental data were subjected to analysis of variance (ANOVA), using Genstat release 6.1 (Lawes 
Agricultural Trust, Rothamsted Experimental Station, U.K.). Effects of different treatments were assessed within ANOVA. Least significant differences (Fisher's protected LSD) were calculated, following significant $F$ test results $(P \leq 0.05)$, and all the assumptions of analysis of variance were checked to ensure validity of the analysis.

\section{Results}

\section{ENDOGENOUS POLYAMINES DURING FRUIT GROWTH AND DEVELOPMENT}

FruIT GROWTH. Fruit diameter growth revealed the typical single sigmoid growth pattern in both cultivars (Fig. 1). On an absolute growth basis (increase per day) (Fig. 2), the fruit development period can be divided into three separate physiological phases: I) (0 to 14 DAFS), when fruit growth was mainly through cell division with little increase in size; II) (15 to 72 DAFS), the main fruit growth period, and III) (73 to 109 DAFS), the maturation period in which there was sharp decline in fruit diameter incremental rate (per day), with rapid gains in fruit weight.

Polyamines. The three major PAs (PUT, SPD and SPM) were detected in both cultivars. Highest concentrations of PAs were found at the time of fruit set ('Kensington Pride', 788 nmol·g ${ }^{-1}$; 'Glen', 736.6 nmol-g ${ }^{-1}$, which generally decreased during fruit development, finally reaching 101 and $89.6 \mathrm{nmol} \cdot \mathrm{g}^{-1}$ in pericarp tissues at maturity in 'Kensington Pride' and 'Glen', respectively (Fig. 4). Mean concentration of SPM was $28 \%$ and $19.6 \%$ higher than PUT and SPD in 'Kensington Pride', while SPD was almost $42 \%$ higher than PUT and SPM in pericarp tissues of 'Glen' (Fig. 3).

Changes in individual PAs in pericarp tissues were greatest during the first 14 DAFS (Fig. 4). Generally, the concentrations of the three PAs decreased with fruit development until 72 DAFS when SPM and PUT started to increase slightly in Kensington Pride, whilst SPD was further reduced toward maturity. At 1 week before harvest, the three PAs were reduced to $21 \%, 10.8 \%$ and $31 \%$, respectively, compared to the levels present at fruit set. Likewise, in 'Glen', PAs were highest at fruit set and gradually reduced to $10.2 \%, 11.6 \%$, and $16.5 \%$ respectively at maturity (Fig. 4).

Comparative Polyamines in OVUle AND PERICARP. The ovule contained $125 \%$ and $168 \%$ higher total PAs than pericarp tissues in 'Kensington Pride' and 'Glen', respectively. Mean free PUT, SPD and SPM were 63\%, $176 \%$, and $84 \%$ higher in ovules compared with pericarp of 'Kensington Pride', while the increase was 3\% (nonsignificant), $172 \%$ and $291 \%$ respectively, in 'Glen' (Fig. 3). In the ovules, the concentration of SPD was higher than SPM and PUT in both cultivars. During fruit development of 'Kensington Pride', the highest level of total free PA in ovules was observed during the early stages of fruit growth (41 to 57 DAFS), corresponding to the high PA contents in the pericarps (Fig 4). Generally the trend in ovules was similar to pericarp tissues, except at maturity, when PAs contents increased in the ovules, but not in the pericarps. The levels of PAs decreased at maturity in both pericarp and ovule, however, the reduction was six times more in pericarp tissues compared with ovules. In 'Glen', such a clear trend was not observed (Fig. 4). An increase in PUT and SPD on 57 and 72 DAFS respectively was observed in the ovule of 'Kensington Pride'. In 'Glen' a similar increase in SPD was observed 72 DAFS (Fig. 4).

\section{ENDOGENOUS POLYAMINES IN NORMAL (SEEDED) AND NUBBINS (SEEDLESS) FRUIT}

Normal-seeded fruit showed higher concentrations of total free PAs (59\%) in pericarp tissues than in nubbins (Fig. 5). SPM and SPD were 3.4- and 2.2-fold higher in normal-seeded fruit than in nubbins. PUT was higher in nubbins, but the means were not significantly different.

Fig. 1. Fruit development of 'Kensington Pride' and 'Glen' mangos. Vertical bars represent SE of means for three replications (10 fruit per replication). LSD ( $P \leq$ 0.05 ) for 'Kensington Pride' (fruit diameter 5.9, weight 29.8) and 'Glen' (fruit diameter 4.6, weight19.7).

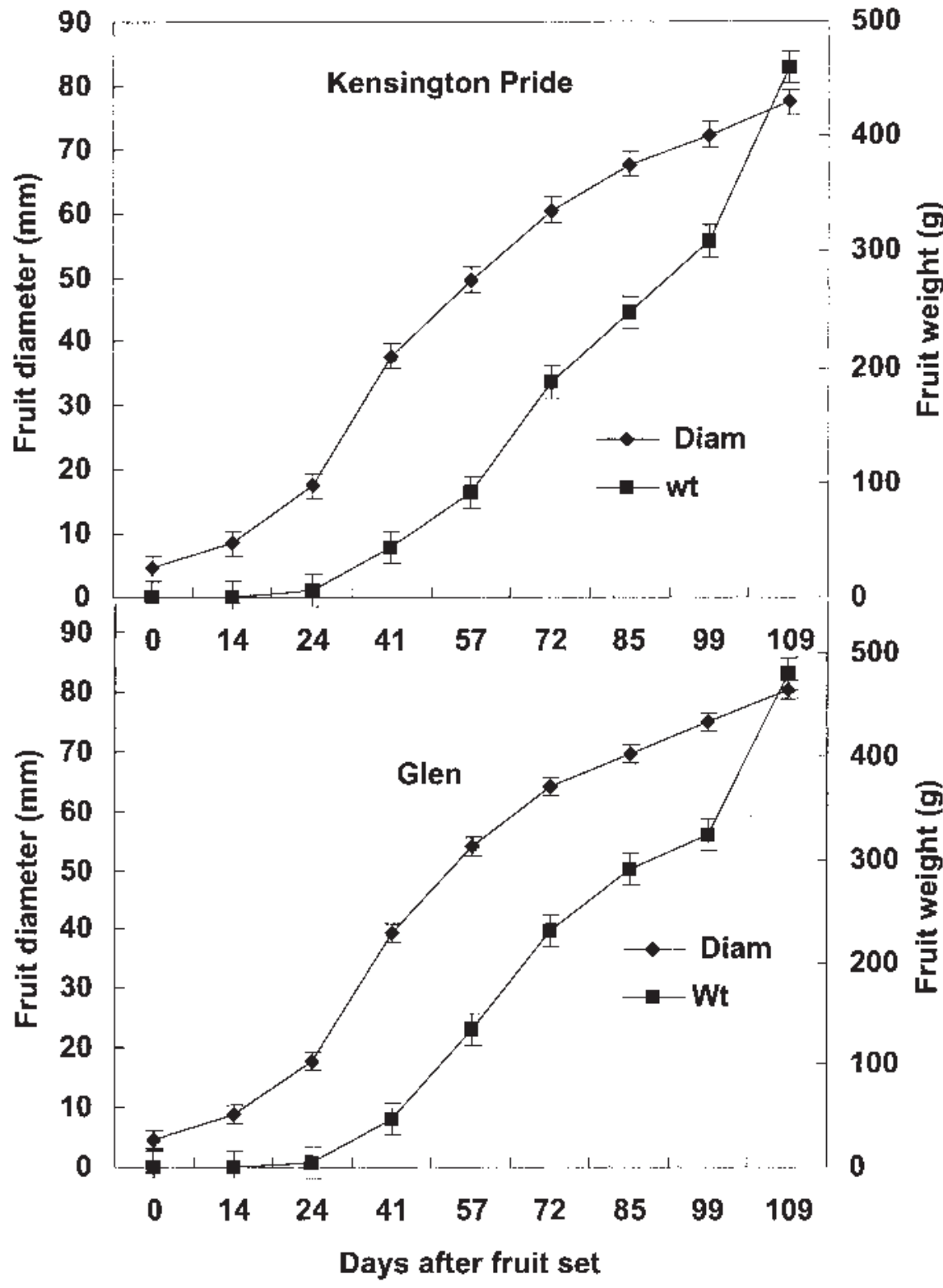




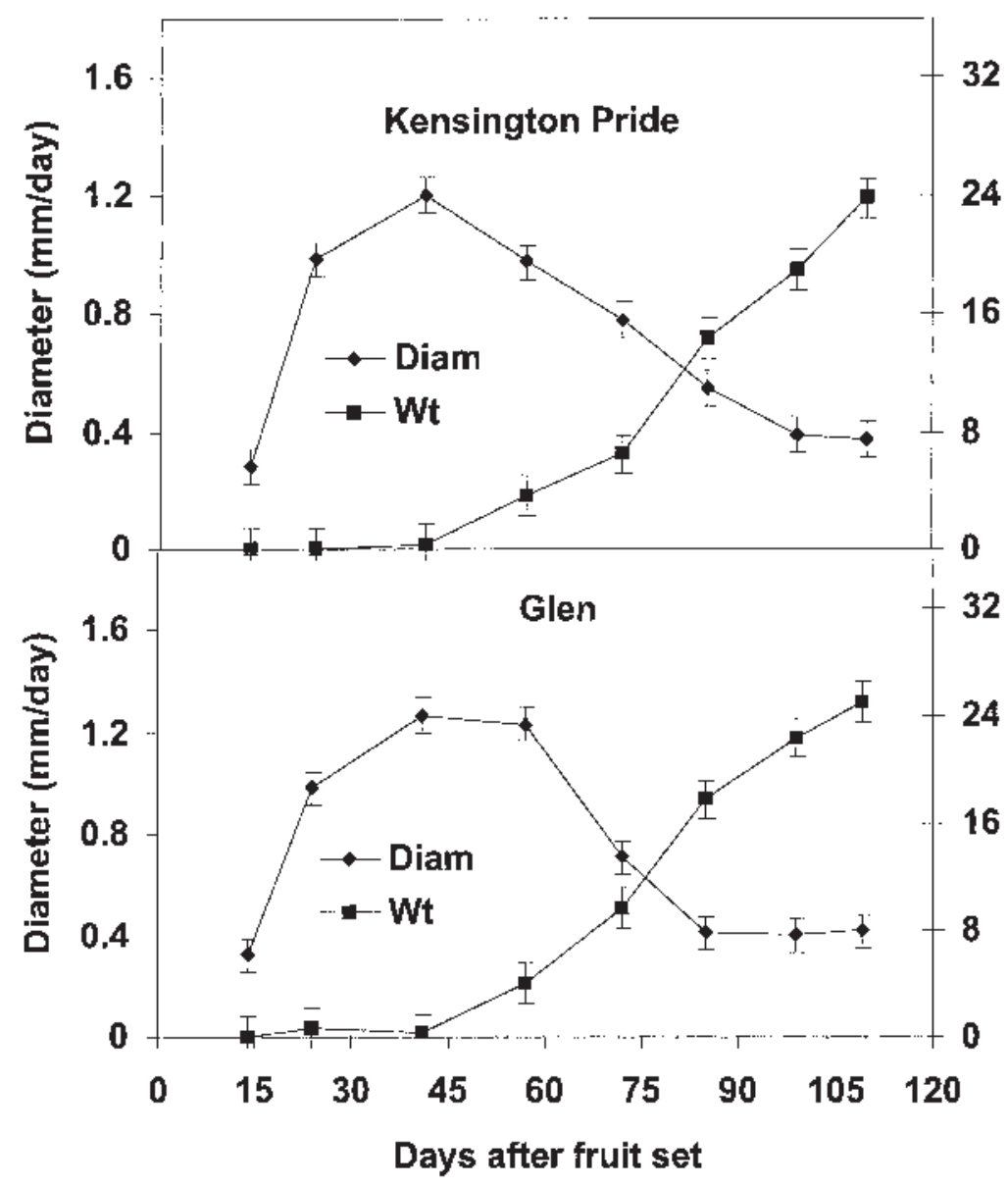

Fig. 2. Absolute growth rate (diameter and weight) patterns of the mango fruit in 'Kensington Pride' and 'Glen'. Vertical bars represents SE of means for three replications (10 fruit per replication). $\mathrm{Wt}=$ fruit weight $(\mathrm{g})$, Diam $=$ diameter $(\mathrm{mm})$. LSD $(P \leq 0.05)$ for 'Kensington Pride' (fruit diameter 0.17, weight 3.8), and 'Glen' (fruit diameter 0.19, weight 4.1).

\section{ENDOGENOUS POLYAMINES AND ETHYLENE DURING FRUIT RIPENING}

Polyamines. PUT, SPD, SPM were also detected during ripening. Skin tissues had $55.8 \%$ higher total free PAs than pulp (Fig. 6A). PUT was the dominant PA both in skin (331 nmol. $\left.\mathrm{g}^{-1}\right)$ and pulp $\left(105 \mathrm{nmol} \cdot \mathrm{g}^{-1}\right)$ followed by SPD and SPM (Table 1). During fruit ripening, the levels of free PAs increased significantly from day 0 to day 4 both in skin and pulp tissues. Generally, the increase in PAs followed the known climacteric pattern. However, as compared to the unripe stage (day 0), the concentration of SPD and SPM in skin increased by $191 \%$, and $107.6 \%$ respectively, at the ripe stage (day 8), while PUT decreased (28.7\%). In the pulp, the increases were $212 \%$, and $210 \%$, respectively, for SPD and SPM; but there was little change in PUT concentrations.

ETHYLENE PRODUCTION. Ethylene levels in 'Kensington Pride' started to increase as ripening advanced. The climacteric peak occurred on day 3 after harvest (Fig 6B).

Fig. 3. Mean free polyamines (PAs) [41 to $109 \mathrm{~d}$ after fruit set (DAFS)] in pericarp and ovule of 'Kensington Pride' and 'Glen' mango. Vertical bars represent SE of means for three replications. LSD tissue type $(P \leq 0.05)$ for 'Kensington Pride' (PUT 28.9, SPD 19, SPM 21.8, total polyamines 57.4) and 'Glen' (PUT 11, SPD 19, SPM 16.5, total 27.5). PUT is nonsignificant in 'Glen'. $\mathrm{PUT}=$ putrescine, $\mathrm{SPD}=$ spermidine, $\mathrm{SPM}=$ spermine, Total $=$ total polyamines.

\section{Discussion}

Fruit growth exhibited a single sigmoidal growth pattern in 'Kensington Pride' and 'Glen' as observed in other mango cultivars (Mendoza, 1981). The three most commonly found free PAs (PUT, SPD and SPM) were identified in mango pericarp and ovule tissues as found in apple (Biasiet al., 1988), cherimoya (Escribano and Merodio, 1994), grape (Shiozaki et al., 2000), and plum (Zuzunaga et al., 2001).

Higher concentrations of PAs, particularly SPM and SPD, in pericarp tissues during the initial period of fruit growth, may be related to the initial active cell division phase as compared to the levels during later stages of growth. Higher levels of free PAs in fruit during early stages of development were also reported in apple, grape and strawberry (Biasi et al., 1988; Ponappa and Miller, 1996; Shiozaki et al., 2000). Rapidly growing cells have higher intracellular concentrations of PAs than the nonproliferating ones (Biasi et al., 1988), and the role of PAs in controlling gene expression more specifically in cell division has been indicated (Bouchereau et al., 1999). Our results suggest the possible relationship between PAs and cell division, but this was not obvious with fruit development at later stages. This may be ascribed to the nature of morphogenetics and physiological effects of PAs which are similar to auxins, but are not directly involved in cell elongation (Bagni, 1986). Further, declining free PAs concentrations in pericarp tissues at later stages of fruit development may be the result

\section{Kensington Pride}
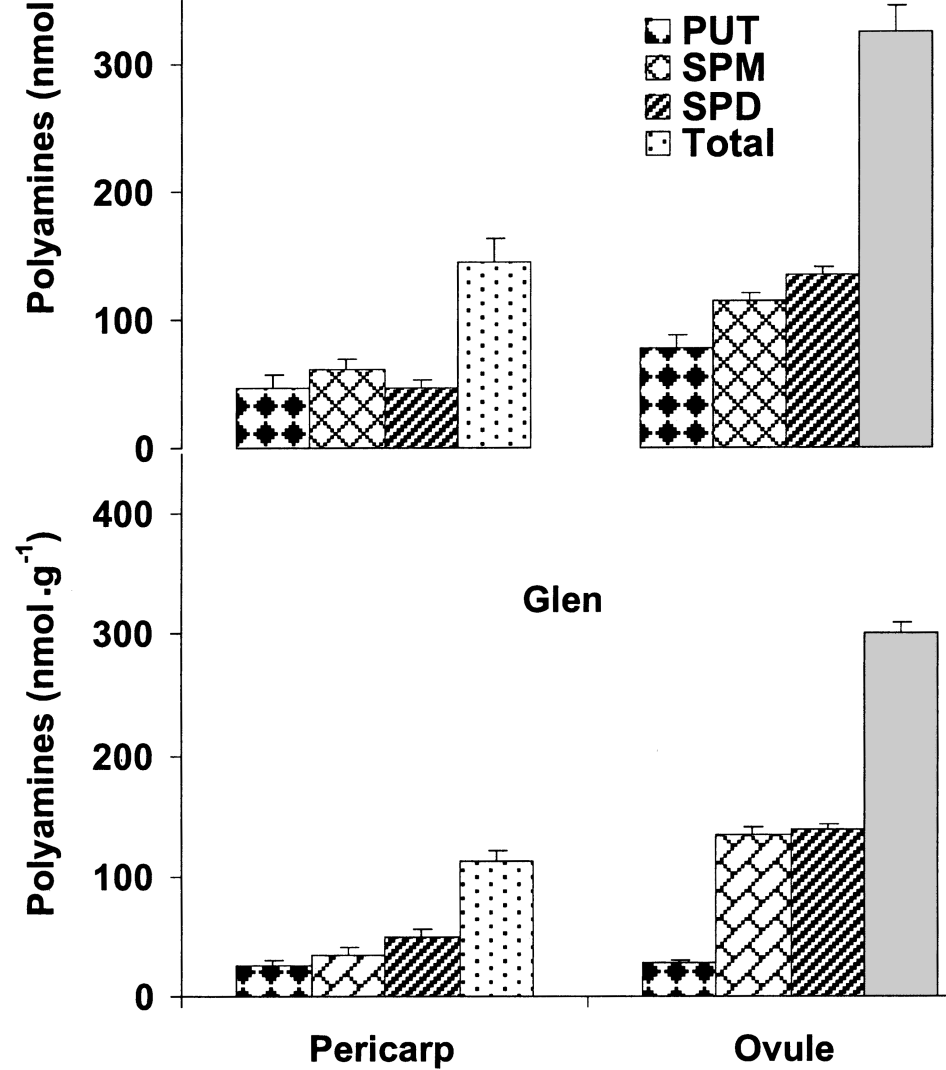
of lower biosynthesis, or conversion to other conjugated forms. In peaches, a reduction in free PAs and an increase in conjugated forms in mesocarp tissues from week 2 to 10 after full bloom has been reported (Kushad, 1998). Higher levels of PAs in early periods of fruit development, which progressively decreased toward maturity, have been reported in pears (Toumadje and Richardson, 1988) and apricots (Paksasorn et al., 1995).

\section{Kensington Pride}

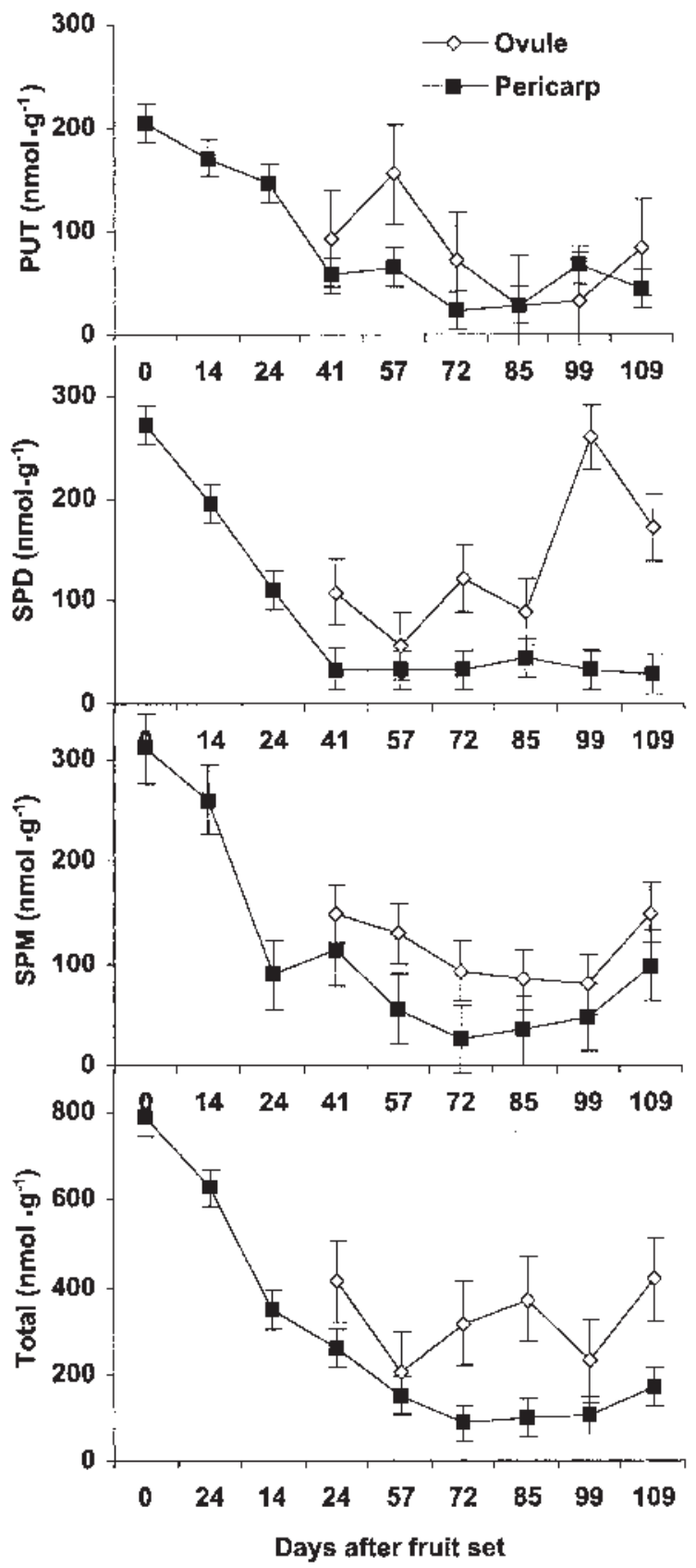

Some previous studies reported PUT as the dominant polyamine in tomato (Morilla et al., 1996) and grape (Shiozaki et al., 2000), but we estimated higher levels of SPM and SPD in the pericarp tissues of 'Kensington Pride' and 'Glen' mango respectively. SPM was found to be dominant in apple at bloom (Biasi et al., 1988) but was undetectable in 'Bartlet' pear, during early developmental stages (Toumadje and Richardson, 1988). Variation in types of PAs

\section{Glen}

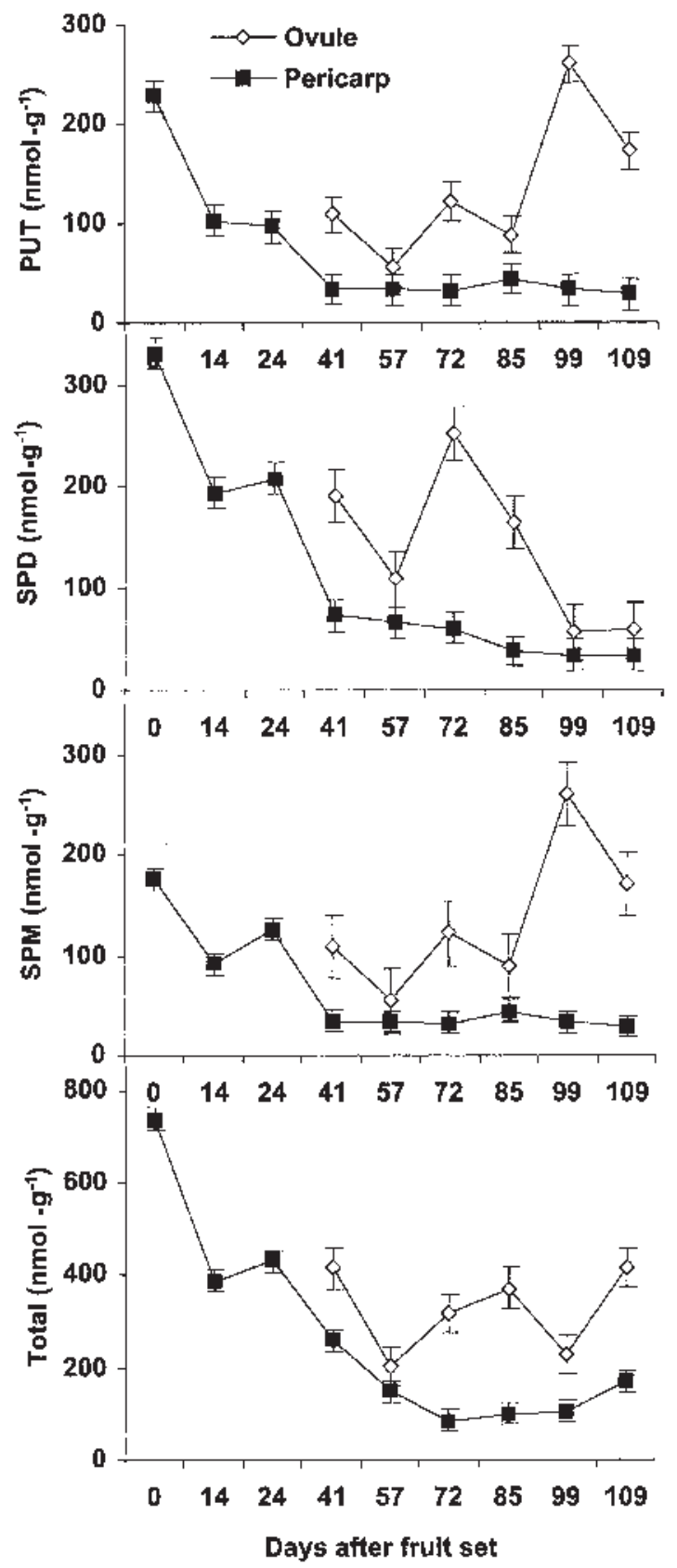

Fig. 4. Changes in PUT, SPD, and SPM in pericarp and ovule of 'Kensington Pride' and 'Glen' mango as related to fruit development. Vertical bars represent SE of means for three replicates $\{$ (Pericarp [(0 and $14 \mathrm{~d}$ after fruit set (DAFS) 10 fruit per replication $(24$ to 109 DAFS) 2 fruit per replication; Ovule $=$ two fruit per replication)\}. LSD $(P \leq 0.05)$ for 'Kensington Pride' (Pericarp: PUT 38.6, SPD 40, SPM 71.8, total polyamines 92; Ovule: PUT 105.2, SPD 72, SPM 65.7, total 213) and 'Glen' (Pericarp: PUT 33, SPD 32, SPM 22.8, total 47.2; Ovule: PUT 41.5, SPD 60, SPM 70, Total 96). PUT = putrescine, SPD = spermidine, SPM = spermine, Total $=$ total polyamines. 


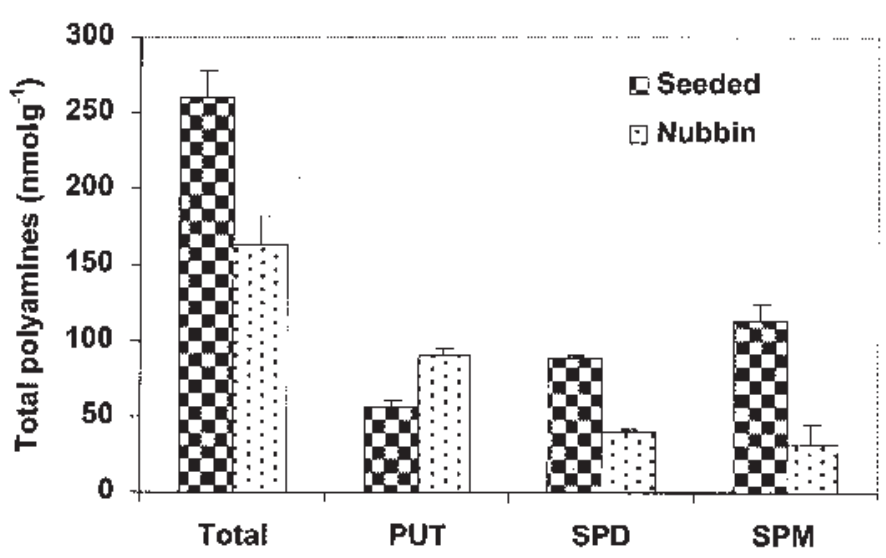

Fig. 5. Endogenous PAs in pericarp of normal (seeded) fruit and nubbins (seedless) fruit of 'Kensington Pride' [41 d after fruit set (DAFS)]. Bars represent SE of means for three replications. LSD $(P \leq 0.05)$ PUT 21.9, SPD 8.2, SPM 55, Total $85 . \mathrm{PUT}=$ putrescine, $\mathrm{SPD}=$ spermidine, $\mathrm{SPM}=$ spermine, Total $=$ total polyamines.

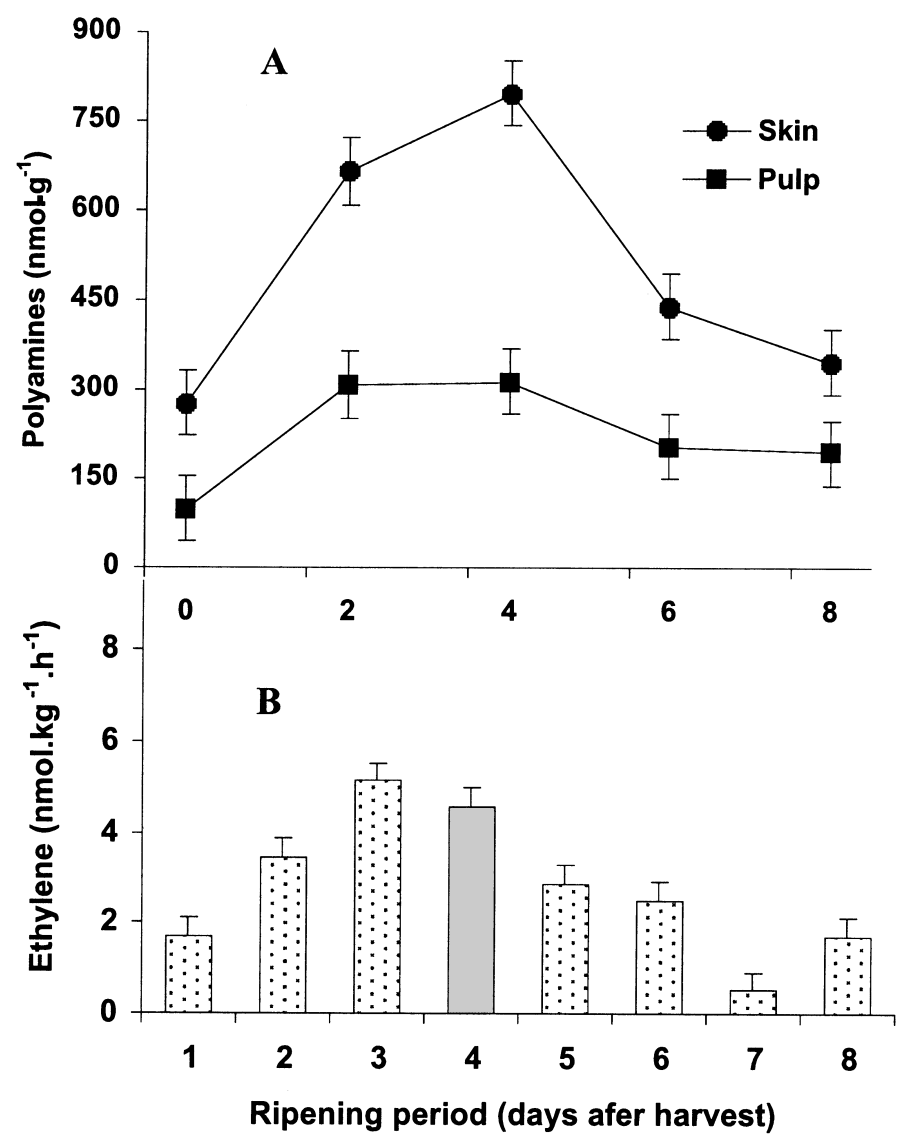

Fig. 6. (A) Changes in endogenous total PAs in skin and pulp during fruit ripening of 'Kensington Pride' mango at $22 \pm 1{ }^{\circ} \mathrm{C}$. (B) Ethylene production during fruit ripening of 'Kensington Pride' mango at $22 \pm 1{ }^{\circ} \mathrm{C}$. Vertical bars represent SE of means for three replications (two fruit per replication for polyamines and single fruit per replication for ethylene). LSD $(P \leq 0.05)$ polyamines \{ripening period 115.9, tissue type 73.3 , ripening period $\times$ tissue type 163.9$)\}$, ethylene $(1.33)$.

seems to be species-specific; however, concentration of individual PAs may vary according to tissue type and stage of growth. Factors affecting PA metabolism in plant tissues at different stages of growth are yet to be investigated.

The ovule contained $45 \%$ and $37 \%$ higher PAs than pericarp tissues of 'Kensington Pride' and 'Glen', respectively, suggesting that mango seeds are active cente of PAs just as they are for other phytohormones (Ram, 1992). In strawberry, achenes have higher levels of total free PAs than receptacle tissues (Ponappa and Miller, 1996). The apparent increase in PUT at 57 DAFS and SPD at 72 DAFS in ovules of 'Kensington Pride', and at 72 DAFS in 'Glen' (Fig. 4) may be related to stress resulting from the endocarp hardening process. A burst in PAs during the pit hardening stage in peach has been reported (Kushad, 1998). The simultaneous changes in PAs contents in ovule and pericarp tissues of 'Kensington Pride' suggests that these changes may be linked, but, this hypothesis was not supported by the PAs changes in 'Glen'. The significantly higher PAs contents in the pericarp of seeded fruit than in nubbins suggest that ovules may have contributed to the free PAs (SPM and SPD) contents of pericarps, but evidence of PA translocation from ovule to pericarp tissues is required to prove this assumption. The reduced size of nubbins (45\% smaller than normal fruit at 41 DAFS, Fig. 2) may be ascribed to the lower cell division rate at initial growth stages due to the limited biosynthesis of PAs, especially SPM and SPD as polyamines have been implicated in plant cell division process (Biasi et al., 1988; Bouchereau et al., 1999).

The increase in free PAs in skin and pulp during mango fruit ripening (Fig. 6) is similar to that in mandarins (Nathan et al., 1984), cherimoya (Escribano and Merodio, 1994), and rambutans (Kondo et al., 2001). The increase in endogenous PAs, especially PUT, is simultaneous with climacteric ethylene production, which suggests that PAs and ethylene may not compete for a common precursor (SAM) for their biosynthesis during mango fruit ripening. Rather, endogenous free PAs, and especially PUT, may have evolved in response to the increased ethylene production. This hypothesis is supported from our recent investigations which showed that application of 500 ppm ethephon to mature green 'Kensington Pride' mango, resulted in 23-fold higher ethylene production, while PAs in the fruit pulp increased simultaneously by $32 \%$ on the second day after treatment compared with control (Malik and Singh, 2003b). An increase in PUT along with climacteric ethylene production has been reported during banana (Musa AAA group, Cavendish subgroup 'Giant Cavendish') fruit ripening (Takeda et al., 1997) and no competitive relationship was found between ethylene and PUT. It has been suggested that a well-defined relationship between ethylene and PA is not seen in all organisms or tissues (Evans and Malmberg, 1989). During fruit ripening, PUT increased in both skin and pulp tissues. The physiological importance of PUT accumulation is not yet clear, although PUT is known to increase in response to various stresses (Bouchereau et al, 1999). In a previous study, pre-and post-harvest applications of PUT resulted in inhibition of ethylene production and delayed mango fruit ripening. However, free PAs in the pulp of treated fruit were also reduced with ethylene inhibition (Malik 2003), which suggests that the inhibition of ethylene may be a direct effect of PAs rather than the result of a competitive biosynthesis relationship. The increase in SPD and SPM at later stages of fruit ripening may be explained on the basis that PUT is metabolized into SPD and SPM.

In summary, the highest levels of endogenous free PAs, especially SPM and SPD, at initial fruit development (0 to 14 DAFS) suggest their possible role in the cell division process. Further, a general decline in their levels toward maturity indicates that free PAs may not be associated with subsequent fruit development. As with other phytohormones, the ovule is a main source of PAs, especially SPM and SPD, but further studies are warranted to determine if the PAs are translocated from ovule to pericarp tissues during mango fruit development. The concurrent increase in PAs and ethylene during mango fruit ripening suggests that endogenous 
Table 1. Endogenous free polyamines on a fresh weight basis, in the skin and pulp during fruit ripening in 'Kensington Pride' mango.

\begin{tabular}{|c|c|c|c|c|c|c|}
\hline \multirow[b]{3}{*}{ Ripening period (day) } & \multicolumn{6}{|c|}{ Polyamines $\left(\mathrm{nmol} \cdot \mathrm{g}^{-1}\right)$} \\
\hline & \multicolumn{3}{|c|}{ Skin } & \multicolumn{3}{|c|}{ Pulp } \\
\hline & PUT & SPD & SPM & PUT & SPD & SPM \\
\hline 0 & 216 & 51.2 & 20.9 & 57 & 29.4 & 13.2 \\
\hline 2 & 415 & 126.3 & 123.7 & 130 & 96.3 & 81.3 \\
\hline 4 & 605 & 137.4 & 54.1 & 185 & 79.3 & 49.1 \\
\hline 6 & 266 & 129.9 & 43.1 & 91 & 71.4 & 41.6 \\
\hline 8 & 154 & 149.1 & 43.4 & 60 & 91.8 & 41 \\
\hline Mean & 331 & 118.8 & 57 & 105 & 73.7 & 45.2 \\
\hline \multicolumn{7}{|l|}{$\operatorname{LSD}(P \leq 0.05)$} \\
\hline Ripening period & \multicolumn{6}{|c|}{$\mathrm{PUT}=102.4, \mathrm{SPD}=20.5, \mathrm{SPM}=25$} \\
\hline Tissue type & \multicolumn{6}{|c|}{$\mathrm{PUT}=64.8, \mathrm{SPD}=12.7, \mathrm{SPM}=\mathrm{NS}$} \\
\hline Ripening period $\times$ tissue type & \multicolumn{6}{|c|}{$\mathrm{PUT}=144.9, \mathrm{SPD}=\mathrm{NS}, \mathrm{SPM}=\mathrm{NS}$} \\
\hline
\end{tabular}

PUT $=$ putrescine, $\mathrm{SPD}=$ spermidine, $\mathrm{SPM}=$ spermine.

Ns Nonsignificant.

PAs may not compete with ethylene for their biosynthesis, but may have evolved in response to ethylene production.

\section{Literature Cited}

Antognoni, F., S. Fornale, C. Grimmer, E. Komor, and N. Bagni. 1998. Longdistance translocation of polyamines in phloem and xylem of Ricinus communis L. plants. Planta 204:520-527.

Bagni, N. 1986. The function and metabolism of polyamines in plants. Acta Hort. 179:95-103.

Biasi, R., N. Bagni, and G. Costa. 1988. Endogenous polyamines in apple and their relationship to fruit set and fruit growth. Physiol. Plant. 73: 201-205.

Biasi, R., G. Costa, and N. Bangi. 1991. Polyamines metabolism as related to fruit set and growth. Plant Physiol. Biochem. 29: 497-506.

Bouchereau, A., A. Aziz, F. Larher, and J. Martin-Tanguy. 1999. Review: Polyamines and environmental changes: Recent developments. Plant Sci. 140:103-125.

Escribano, M.I. and C. Merodio. 1994. The relevance of polyamine levels in cherimoya (Annona cherimola Mill.) fruit ripening. J. Plant Physiol. 143: 207-212.

Evans, T.P. and R.L. Malmberg. 1989. Do polyamines have a role in plant development? Annu. Rev. Plant Physiol. Plant Mol. Biol. 40:235-269.

Flores, H. E. and A.W. Galston. 1982. Analysis of polyamines in higher plants by high performance liquid chromatography. Plant Physiol. 69:701-706.

Geny,L., M. Broquedis, J. Martin Tanguy, and J. Bouard. 1997. Free, conjugated, and wall-bound polyamines in various organs of fruiting cuttings of Vitis vinifera L. cv. Cabernet Sauvignon. Amer. J. Enol. Viticult. 48:80-84.

Johnson, P.R. and D. Parr, 1998. Mango growing in Western Australia, tropical and sub-tropical fruits. Agdex 234/01, Agriculture, W. Austral., Bul. 4348.

Kakkar, R.K. and V.K. Rai. 1993. Plant polyamines in flowering and ripening. Phytochemistry 33:1281-1288.

Kondo, S., P. Posuya, and S. Kanlayanarat. 2001. Changes in physical characteristics and polyamines during maturation and storage of rambutans. Scientia Hort. 91:101-109.

Kumar, A., M.A. Taylor, S.A.M. Arif, and H.V. Davies. 1996. Potato plants expressing antisense and sense S-adenosylmethionine decarboxylase (SAMDC) transgenes show altered levels of polyamines and ethylene: antisense plants display abnormal phenotypes. Plant J. 9:147-158.

Kushad, M.M. 1998. Changes in polyamine levels in relationship to the doublesigmoidal growth curve of peaches. J. Amer. Soc. Hort. Sci. 123:950-955.

Lester, G.E. 2000. Polyamines and their cellular anti-senescence properties in honey dew muskmelon fruit. Plant Sci. 160:105-112.

Malik, A.U. 2003. Fruitlet abscission and fruit ripening of mango in relation to polyamines. $\mathrm{PhD}$ thesis. Curtin Univ. Technol., Perth, W. Ausral.

Malik, A.U. and Z. Singh. 2003a. Abscission of mango fruitlets as influenced by biosynthesis of polyamines. J. Hort. Sci. Biotechnol. 78:721-727.

Malik, A. U. and Z. Singh. (2003b). Increased biosynthesis of free polyamines in response to higher ethylene production during fruit ripening of mango, $\mathrm{p}$. 117-119. Proc. Austral. Postharvest Hort. Conf., Brisbane, 1-4 Oct. 2003.

Malmberg, R.L., M.B. Watson, G.L. Galloway, W. Yu, and W. Yu. 1998. Molecular genetic analyses of plant polyamines. Crit. Rev. Plant Sci. 17: 199-224.

Mendoza, D.B. 1981. Development physiology of 'Carabao'mango (Mangifera indica $\mathrm{L}$.) fruit. $\mathrm{PhD}$ thesis. Univ. Philipines, Laguna.

Morilla, A., J.M. Garcia, and M.A. Albi. 1996. Free polyamine contents and decarboxylase activities during tomato development and ripening. J. Agr. Food Chem. 44:2608-2611.

Murti, G.S.R. and K.K. Upreti. 1995. Changes in some endogenous growth substances during fruit development in mango. Plant Physiol. Biochem. 22:44-47.

Murti, G.S.R. and K.K. Upreti. 1999. Endogenous hormones and polyamines in relation to fruitlet retention in mango cv. Alphonso. J. Plant Biol. 26: $149-154$.

Nair, S. 2002. Biochemcal aspects of chilling injury of mango (Mangifera indica L.) fruit. $\mathrm{PhD}$ thesis. Curtin Univ. Technol., Perth, W. Austral.

Nathan, R., A. Altaman, and S.P. Monselise. 1984. Changes in activity of polyamine biosynthetic enzymes and polyamine contents in developing fruit tissues of 'Murcott' mandarin. Scientia Hort. 22:359-364.

Nitsch, J.P. 1970. Hormonal factors in growth and development, p. 427-472. In: A.C. Hulme (ed.). The biochemistry of fruits and their products. Academic Press, London.

Paksasorn, A., T. Hayasaka, H. Matsui, H. Ohara, and N. Hirata. 1995. Relationship of polyamine content to ACC content and ethylene evolution in Japanese apricot fruit. J. Jpn. Soc. Hort. Sci. 63:761-766.

Ponappa, T. and A.R. Miller. 1996. Polyamines in normal and auxin-induced strawberry fruit development. Physiol. Plant. 98:447-454.

Ram, S. 1992. Naturally occurring hormones of mango and their role in growth and drop of the fruit. Acta Hort. 321:400-411.

Shiozaki, S., T. Ogata, and S. Horiuchi. 2000. Endogenous polyamines in the pericarp and seed of the grape berry during development and ripening. Scientia Hort. 83:33-41.

Smith, T.A. 1985. Polyamines. Annu. Rev. Plant Physiol. 36:117-143.

Takeda, Y., K.I. Yoza, Y. Nogata, K.I. Kusumoto, A.G.J. Voragen, and H. Ohta. 1997. Putrescine accumulation in banana fruit with ripening during storage. Phytochemistry 46:57-60.

Toumadje, A. and D.G. Richardson. 1988. Endogenous polyamine concentrations during development, storage, and ripening of pear fruits. Phytochemistry 27:335-338.

Whangchai, K., H. Gemma, S. Iwahori, and J. Uthaibutra. 2000. Endogenous polyamines in 'Nam Dok Mai' mangoes with different ripening stages and its relation to chilling injury during storage. Acta Hort. 509:429-436.

Zuzunaga, M., M. Serrano, D. Martinez Romero, D. Valero, and F. Riquelme. 2001. Comparative study of two plum (Prunus salicina Lindl.) cultivars during growth and ripening. Food Sci. Technol. Intl. 7:123-130. 